\title{
MAMPUKAH BADAN USAHA MILIK DESA MENERAPKAN KEADILAN PROSEDURAL?
}

\author{
Marryella Violetha Patiran ${ }^{1}$ \\ Fakultas Ekonomika dan Bisnis, Universitas Kristen Satya Wacana, Indonesia \\ 232016211@student.uksw.edu
}

\begin{abstract}
Intiyas Utami ${ }^{2}$
Fakultas Ekonomika dan Bisnis, Universitas Kristen Satya Wacana, Indonesia intiyas.utami@student.uksw.edu
\end{abstract}

Diterima 1 Mei 2020

Disetujui 20 Mei 2020

\begin{abstract}
The objective of this research to explore the ability of Village-owned enterprise in realizing procedural justice. Village-Owned Enterprises should be able to provide justice for its members, but whether they are able to provide procedural justice to stakeholders, namely administrators and village communities. Research on Village-Owned Enterprises is mostly carried out in terms of governance in general, whereas specifically procedural justice has the potential to be investigated as part of governance implementation. This research was conducted with a qualitative method that traced the facts of procedural justice in the Karya Lestari Manunggal Village Company in Boyolali District. Data in the form of interviews with resource persons, namely the management of the Village Owned Enterprises and community representatives. The results of this study indicate that procedural justice cannot yet be fully realized in the Kalem Village-Owned Enterprises due to limited human resources. Conditions of procedural justice that can be realized in terms of the delivery of information in the Village Development Planning Consultation have been carried out. Procedural justice in villageowned enterprises still needs to be optimized by increasing the capacity of human resources. The Office of Community Empowerment in Boyolali District can provide more intensive training to improve human resources.
\end{abstract}

\section{Keywords: Village-Owned Enterprises, Procedural Justice}

\section{PENDAHULUAN}

Banyaknya penelitian yang dilakukan terhadap organisasi sektor swasta terhadap keadilan prosedural dalam manajemen tata kelola perusahaannya, memberikan ketertarikan untuk melihat penerapan keadilan prosedural dari organisasi sektor publik yaitu BUM Desa. Tujuan dari penelitian ini adalah untuk menjelaskan kondisi keadilan prosedural di BUM Desa Kalem dari segi pengelola BUM Desa dan masyarakat desa. Penelitian dilaksanakan di BUM Desa Kalem karena usaha pengurus operasional BUM Desa yang berupaya untuk melibatkan masyarakat desa dalam berbagai aktivitas maupun kegiatan yang diselenggarakan BUM Desa Kalem. Penelitian menemukan bahwa keadilan prosedural belum sepenuhnya mampu menerapkan keadilan prosedural karena keterbatasan SDM. 


\subsection{Latar Belakang Masalah}

Peningkatan jumlah penduduk yang signifikan mengakibatkan ketidakseimbangan pemerataan kesejahteraan di kalangan masyarakat terutama di pedesaan. Jumlah desa yang tertinggal ialah sebesar 17.616 dari total 74.957 desa (www.kemendesa.go.id). Dalam rangka menanggulangi hal tersebut, pemerintah berupaya dengan mengalokasikan dana desa atas pertimbangan luas wilayah desa, letak geografis desa, angka kemiskinan serta jumlah penduduk desa tersebut (Menteri Keuangan Republik Indonesia, 2017). Pengelolaan dana desa kemudian akan dikelola dan diatur sendiri oleh desa yang dituju.

Pengelolaan dana desa harus dapat mengarah pada praktik tata kelola perusahaan yang baik sehingga dapat memberikan pertanggungjawaban atas anggaran dan kegiatan yang dilaksanakan. Konsep tata kelola perusahaan yang baik memiliki beberapa komponen yang dapat dijadikan acuan dalam pembuatan keputusan sehingga konsep ini dapat diterapkan oleh desa. Nahruddin (2014) menyatakan bahwa dalam pengelolaan keuangan desa diperlukan penerapan prinsip akuntabilitas dan transparansi sebagai sarana untuk mempertanggungjawabkan berbagai kegiatan yang dilaksanakan. Arifuddin et al. (2017) mengungkapkan bahwa pemerintah yang baik harus mampu mengelola keuangan daerah berdasarkan peraturan perundang-undangan yang ditetapkan dengan menerapkan prinsip akuntabilitas dan transparansi. Kedua penelitian tersebut memberikan hasil bahwa penerapan prinsip akuntabilitas dan transparansi sudah diterapkan dengan baik dalam pengelolaan keuangan desa di Desa Pao-Pao Kecamatan Tanete Rilau Kabupaten Barru dan salah satu desa di Kecamatan Mawasangka Kabupaten Buton Tengah.

Nugrahaningsih et al. (2016); Sugiarti dan Yudianto (2017) mengungkapkan bahwa posisi desa sebagai fokus utama pembangunan memberikan suatu keharusan bagi pemerintah desa untuk meningkatkan kualitas pelayanannya dengan prinsip akuntabilitas. Kedua penelitian tersebut menyebutkan bahwa pelaksanaan prinsip akuntabilitas dalam pengelolaan keuangan desa harus didukung oleh sumber daya manusia (SDM) yang berkualitas serta sarana dan prasarana yang memadai misalnya penyediaan fasilitas teknologi informasi. Penggunaan dana desa yang optimal diharapkan dapat memacu laju pertumbuhan ekonomi wilayah pedesaan. Optimalisasi penggunaan dana desa salah satunya dapat dilakukan dengan pengembangan badan usaha milik desa (BUM Desa) sebagai upaya untuk mengembangkan ekonomi masyarakat desa.

Pendirian BUM Desa ditujukan bagi pengembangan potensi masyarakat berupa pengetahuan dan kreativitas yang dimiliki (www.berdesa.com). Dalam pengelolaan BUM Desa terdapat beberapa pihak yang ikut serta dalam penyertaan modal. Pasal 17 Peraturan Menteri Desa, Pembangunan Daerah Tertinggal, dan Transmigrasi Republik Indonesia Nomor 4 Tahun 2015 tentang Pendirian, Pengurusan dan Pengelolaan, dan Pembubaran Badan Usaha Milik Desa menyebutkan bahwa "Modal BUM Desa terdiri atas: a. penyertaan modal Desa; dan b. penyertaan modal masyarakat Desa" (Menteri Desa, Pembangunan Daerah Tertinggal, dan Transmigrasi Republik Indonesia, 2015:7). Hal ini berarti bahwa tidak hanya pemerintah saja yang berkontribusi dalam menyertakan modal bagi BUM Desa tetapi juga ada masyarakat desa yang turut serta dalam penyertaan modal tersebut. Oleh sebab itu, tidak boleh terdapat pemberian hak-hak yang istimewa yang dapat memunculkan intervensi berlebihan dari pihak tertentu. Intervensi dari pemerintah merupakan salah satu faktor penghambat bagi desa dalam mengeksplorasi potensi yang dimiliki. BUM Desa merupakan solusi yang tepat bagi upaya pengembangan perekonomian desa karena BUM Desa dibentuk untuk tidak mengalami intervensi dari berbagai pihak.

Di sisi lain, BUM Desa sebagai lembaga ekonomi seharusnya memiliki tata kelola yang baik karena BUM Desa juga beroperasi dalam rangka kepentingan publik. Artati dan Utami 
(2020) menyatakan bahwa BUM Desa Bareng Nyawiji memiliki kemampuan dan kemauan untuk membuat laporan keuangan yang akuntabel tetapi ketidakdisiplinan pengelola BUM Desa dan faktor budaya Jawa menjadi penghambat akuntabilitas BUM Desa Bareng Nyawiji. Wulandari dan Utami (2020) menyebutkan bahwa mekanisme pertanggungjawaban di BUM Desa Kalem dianggap tidak optimal dikarenakan kurangnya sumber daya manusia dan rendahnya minat masyarakat untuk berpartisipasi dalam pengelolaan BUM Desa Kalem. Tantri dan Utami (2019) menemukan bahwa transparansi dan responsibilitas di BUM Desa Bersama Utama belum optimal karena adanya keterbatasan akses bagi masyarakat untuk melihat laporan keuangan BUM Desa dan adanya kelemahan dalam tahap penatausahaan.

Tata kelola organisasi yang tepat akan mendukung pengelolaan BUM Desa yang adil sehingga memberikan kepuasan bagi masyarakat desa. Pengelolaan organisasi yang adil dapat meningkatkan kinerja manajerial melalui penerapan keputusan-keputusan yang mewakili individu-individu yang berkepentingan (Syah, 2013). Pada BUM Desa, hal ini berarti penerapan keadilan menyebabkan masyarakat desa sebagai pihak yang berkepentingan dapat secara aktif berpartisipasi dalam pengelolaan BUM Desa. Partisipasi masyarakat desa merupakan hal yang penting bagi BUM Desa karena BUM Desa hadir untuk menguatkan instrumen kesejahteraan masyarakat dengan cara meminimalisir tingkat pengangguran di wilayah pedesaan (Budiono, 2015). Berkaitan dengan penerapan keadilan di BUM Desa, Cropanzano et al. (2011) membagi keadilan dalam organisasi menjadi tiga bagian yaitu keadilan distributif yang berkaitan dengan pengalokasian sumber daya, keadilan prosedural yang berhubungan dengan keadilan dalam pembuatan keputusan, serta keadilan interaktif yang mengacu pada hubungan antar pribadi dalam organisasi. Berdasarkan fenomena yang telah dijelaskan bahwa partisipasi dan kontribusi masyarakat desa merupakan hal yang penting dalam pengelolaan BUM Desa, maka BUM Desa sangat perlu untuk menerapkan keadilan prosedural dalam tata kelola organisasinya.

Josef (2017) menyatakan bahwa karyawan dapat bertindak kontraproduktif pada organisasi jika diperlakukan secara tidak adil dalam penerapan prosedur organisasi. Maspaitella et al. (2018) menyatakan bahwa keadilan dalam bentuk penerapan aturan yang tegas akan sejalan dengan rasa puas karyawan dalam bekerja. Clarke et al. (2013) mengungkapkan bahwa terdapat unsur ketidakadilan yang dirasakan karyawan terutama pada komponen keadilan dalam pemberian informasi yang memadai dan penilaian berdasarkan bukti. Ketiga penelitian tersebut memberikan penjelasan bahwa keadilan prosedural yang diterapkan dengan cara penerapan peraturan secara tegas, penilaian kinerja berdasarkan bukti, pemberian informasi yang memadai, serta diperlakukan adil oleh pimpinan organisasi akan berdampak positif pada kinerja dan sikap karyawan.

Irawan dan Sudarma (2016) menerangkan bahwa penerapan keadilan prosedural pada karyawan akan memberikan dampak positif bagi perusahaan karena hal tersebut memberikan rasa puas dalam bekerja sehingga menimbulkan komitmen afektif dalam diri karyawan. Bohle dan Alonso (2016) menemukan bahwa penerapan keadilan prosedural dapat menghilangkan rasa tidak aman ketika bekerja dan memberikan dampak yang baik pada perilaku karyawan. Hasil dari kedua penelitian tersebut menjelaskan bahwa penerapan keadilan prosedural akan memberikan dampak yang baik bagi kelangsungan organisasi karena karyawan memberikan pengaruh yang positif melalui perilaku dan komitmennya.

Berdasarkan wawancara yang dilakukan terhadap peserta Mental Health Court (MHC), ditemukan bahwa penerapan keadilan prosedural dilakukan dengan cara melibatkan peserta MHC dalam pengambilan keputusan meski tidak semua pembuatan keputusan melibatkan peserta MHC (Canada dan Watson, 2013). Goodman-Delahunty et al. (2014) menyatakan bahwa berdasarkan hasil wawancara yang dilakukan kepada praktisi berpengalaman yang 
bekerja pada salah satu dari lima negara Asia Pasifik, keadilan prosedural diterapkan untuk mendapatkan informasi yang andal dan tujuan pekerjaan. Simcock (2016) menemukan bahwa keadilan prosedural dalam komunitas proyek yang diteliti diterapkan melalui pengambilan keputusan yang melibatkan pemangku kepentingan.

Penelitian-penelitian yang dilakukan oleh Arifuddin et al. (2017); Nahruddin (2014); Nugrahaningsih et al. (2016); Sugiarti dan Yudianto (2017) merupakan riset yang membahas tentang pengelolaan keuangan desa yang mengarah pada penerapan asas praktik tata kelola yang baik. Penelitian yang dilakukan oleh Artati dan Utami (2020); Tantri dan Utami (2019); Wulandari dan Utami (2020) adalah penelitian tentang penerapan tata kelola BUM Desa. Sedangkan riset yang dilakukan oleh Bohle dan Alonso (2016); Canada dan Watson (2013); Clarke et al. (2013); Cropanzano et al. (2011); Goodman-Delahunty et al. (2014); Irawan dan Sudarma (2016); Josef (2017); Maspaitella et al. (2018); Simcock (2016) merupakan penelitian yang menjelaskan bahwa penerapan keadilan prosedural dalam organisasi sektor swasta akan memberikan dampak yang positif pada respon dan perilaku karyawan. Keadilan prosedural juga diterapkan melalui keterlibatan pihak yang berkepentingan dalam pembuatan keputusan. Risetriset tersebut memberikan celah bagi penelitian ini untuk membahas penerapan keadilan prosedural di unit usaha desa yaitu Badan Usaha Milik Desa (BUM Desa). Hal ini dikarenakan pengungkapan yang dilakukan terkait tindak keadilan prosedural telah banyak dilakukan pada organisasi sektor swasta. Sedangkan pada organisasi sektor publik yaitu BUM Desa, keadilan prosedural juga dapat diterapkan karena relevan dengan BUM Desa yang merupakan organisasi milik masyarakat desa. Dalam hal ini keadilan prosedural merupakan bagian dari proses penerapan keadilan dalam organisasi yang mengarah pada prinsip praktik tata kelola yang baik.

Desa Kemasan, Kecamatan Sawit, Kabupaten Boyolali merupakan salah satu desa yang telah mendirikan BUM Desa pada tahun 2016 yang aktivitas operasional utamanya adalah pengelolaan tempat wisata. BUM Desa tersebut diberi nama Karya Lestari Manunggal (Kalem). Tempat wisata yang dikelola BUM Desa Kalem salah satunya ialah wisata edukasi yaitu belajar menanam padi, membuat jamu tradisional, membuat kerupuk dari kangkung, pergi ke tempat peternakan sapi dan masih banyak lagi. Selain itu, BUM Desa Kalem juga menyediakan wisata alam dan wisata kuliner dengan berbagai sarana yaitu kolam renang, pendopo, dan gazebo yang dikelilingi oleh tanaman hijau. Upaya pengelola BUM Desa Kalem dalam mengembangkan BUM Desa memberikan ketertarikan untuk meneliti penerapan keadilan prosedural di Badan Usaha Milik Desa Karya Lestari Manunggal. Hal ini dikarenakan upaya pengelola dapat mencerminkan usahanya dalam melibatkan peran aktif masyarakat desa yang sesuai dengan konsep keadilan prosedural dalam menerapkan prosedur yang tidak bias dan mengutamakan pihak-pihak yang berkepentingan.

\subsection{Rumusan Masalah}

BUM Desa merupakan badan usaha yang didirikan dalam rangka mengoptimalkan potensi wilayah pedesaan. Dalam hal ini, peran aktif masyarakat desa sangat diperlukan guna mencapai tujuan berdirinya BUM Desa yaitu untuk meningkatkan perekonomian masyarakat desa melalui pengembangan usaha ekonomi masyarakat. Tata kelola yang baik akan membantu BUM Desa dalam mencapai tujuannya. Keadilan prosedural merupakan salah satu unsur dari kesetaraan dan kewajaran dalam tata kelola yang harus diterapkan BUM Desa. Penerapan keadilan prosedural pada BUM Desa akan menjelaskan upaya pengurus operasional BUM Desa untuk meningkatkan peran aktif masyarakat desa dalam pengelolaan BUM Desa. Melalui penerapan keadilan prosedural juga akan menunjukkan respon masyarakat desa atas upaya yang dilakukan pengurus operasional BUM Desa. Terdapat tiga komponen keadilan prosedural di antaranya pemberitahuan yang memadai, penyampaian yang adil, dan penilaian berdasarkan bukti. 


\subsection{Manfaat Penelitian}

Selanjutnya, kontribusi dalam penelitian ini ialah bagi pengelola BUM Desa beserta Dinas Pemberdayaan Masyarakat dan Desa dalam menyusun, melaksanakan, dan mengawasi kebijakan yang berkaitan dengan BUM Desa sehingga kebijakan yang ditetapkan mampu berdampak pada keterlibatan masyarakat desa. Manfaat teoritis yang diperoleh dari penelitian ini ialah menambah wawasan dalam konsep keadilan prosedural dari segi organisasi sektor publik yaitu BUM Desa.

\section{TINJAUAN PUSTAKA DAN HIPOTESIS}

\subsection{Badan Usaha Milik Desa (BUM Desa)}

Badan usaha milik desa merupakan sebuah unit usaha yang dibangun dan didirikan oleh pemerintah desa yang pengelolaannya dilakukan oleh pemerintah desa dan masyarakat desa (Ramadana et al., 2013). BUM Desa dibentuk berdasarkan potensi yang dimiliki oleh desa (Farokhah dan Sapoetra, 2018). Pendirian badan usaha milik desa merupakan langkah utama dalam menciptakan kemandirian perekonomian desa serta salah satu upaya pemerintah dalam rangka pengentasan kemiskinan yang terjadi di wilayah pedesaan (Hayyuna et al., 2014; Kasila dan Kolopaking, 2018). Selanjutnya, pembangunan BUM Desa dilakukan atas gagasan pemikiran masyarakat desa serta bentuk penyertaan modal dapat berasal dari masyarakat desa, pemerintah desa, bantuan pemerintah kabupaten, maupun dengan melakukan peminjaman dana ke pemerintah desa atau pihak lainnya (Shaffitri et al., 2015). Dalam melaksanakan kegiatan operasional, BUM Desa harus dapat memberikan pelayanan yang tidak berat sebelah dan selalu dapat mempertahankan kualitas dari produk ataupun jasa yang dijual (Iskamto et al., 2018).

BUM Desa memiliki peran sebagai instrumen dalam menguatkan otonomi desa dan instrumen kesejahteraan masyarakat. Instrumen otonomi desa berarti bahwa BUM Desa membantu mendorong pemerintah desa dalam mengembangkan potensi yang dimiliki desa sesuai dengan kemampuan dan kewenangan desa. Sedangkan instrumen kesejahteraan masyarakat berarti bahwa BUM Desa melibatkan masyarakat dalam pengelolaan organisasinya sehingga dapat mengurangi tingkat pengangguran yang terjadi (Budiono, 2015). BUM Desa juga sangat berguna bagi pemanfaatan produk lokal sehingga mampu meningkatkan kesejahteraan karena masyarakat desa memiliki sumber penghasilan tambahan dan kepastian harga dapat terjamin (Suryana et al., 2015). Hal ini berarti bahwa BUM Desa merupakan unit usaha yang dibangun dalam rangka meningkatkan perekonomian wilayah pedesaan dengan melibatkan peran aktif masyarakat desa melalui pemanfaatan produk lokal.

Sehubungan dengan pengertian, tujuan, dan manfaat dari BUM Desa, pembentukan BUM Desa yang bermula dari musyawarah desa memberikan susunan kepengurusan di dalam organisasi tersebut. Pasal 10 Peraturan Menteri Desa, Pembangunan Daerah Tertinggal, dan Transmigrasi Republik Indonesia Nomor 4 Tahun 2015 tentang Pendirian, Pengurusan dan Pengelolaan, dan Pembubaran Badan Usaha Milik Desa menyebutkan bahwa "Susunan kepengurusan organisasi pengelola BUM Desa terdiri dari: a. Penasihat; b. Pelaksana operasional; dan c. Pengawas". Peraturan tersebut juga menyebutkan bahwa "BUM Desa dapat menjalankan usaha bersama (holding) sebagai induk dari unit-unit usaha yang dikembangkan masyarakat Desa baik dalam skala lokal Desa maupun kawasan perdesaan". Hal ini berarti bahwa dalam susunan kepengurusan tersebut, BUM Desa dapat membawahi setiap unit-unit usaha yang beroperasi (Menteri Desa, Pembangunan Daerah Tertinggal, dan Transmigrasi Republik Indonesia, 2015:5-8). 


\subsection{Keadilan Prosedural dalam Tata Kelola Badan Usaha Milik Desa}

Tata kelola perusahaan yang baik adalah rancangan dalam organisasi yang berguna untuk menaikkan nilai perusahaan melalui pengawasan kinerja dan menjaga akuntabilitas manajemen yang berdasarkan pada peraturan (Pahlawan et al., 2018). Penerapan tata kelola perusahaan yang baik merupakan dasar dalam pengelolaan suatu usaha dan bertujuan agar dapat mendorong pengelolaan organisasi yang profesional, transparan, akuntabilitas, adil, serta dapat dipercaya dan bertanggung jawab (Septiawan, 2018). Negrut et al. (2010) menjelaskan bahwa tata kelola perusahaan yang baik merupakan konsep yang memperhitungkan keterlibatan warga negara dalam proses pengambilan keputusan, kebutuhan, dan permintaan mereka serta bertujuan untuk kepentingan umum.

Sejalan dengan pengertian tata kelola perusahaan yang baik, BUM Desa sebagai organisasi sektor publik juga memiliki tata kelola dalam organisasinya. Tata kelola BUM Desa merupakan seperangkat peraturan yang dibuat untuk menjadi pedoman dalam melaksanakan kegiatan operasionalnya. Tata kelola tersebut dirancang dengan tujuan agar BUM Desa mampu bekerja secara profesional serta mampu mempertanggungjawabkan kegiatan dan anggaran yang telah direalisasikan. Pelaksanaan tata kelola pada BUM Desa harus dapat mengarah pada prinsip praktik tata kelola yang baik. UU Nomor 32 Tahun 2004 tentang Pemerintahan Daerah memberikan jaminan terhadap pelaksanaan prinsip praktik tata kelola yang baik secara efektif, efisien, transparan, akuntabel, tertib, setara, dan taat pada peraturan perundang-undangan (Prasojo et al., 2014).

Perlakuan yang setara (fairness) menjelaskan bahwa para pengelola usaha harus dapat memperlakukan semua pemangku kepentingan secara adil dan setara (Agoes dan Ardana, 2014). Perlakuan yang adil pada pemangku kepentingan dapat dikategorikan sebagai keadilan prosedural yaitu bentuk penerapan proses yang konsisten, beretika, bebas dari bias, akurat, dan representatif dari pemangku kepentingan yang relevan. Keadilan prosedural merupakan bagian dari penerapan keadilan dalam organisasi (Cropanzano et al., 2011).

Dalam perusahaan, model keadilan prosedural dengan pendekatan dalam penilaian kinerja memiliki tiga unsur utama (Folger et al., 1992). Pertama, pemberitahuan yang memadai (adequate notice) yang menerangkan bahwa sebelum tujuan dan standar ditetapkan maka hal tersebut perlu untuk diterbitkan, didistribusikan secara luas, dan dijelaskan. Dalam hal ini karyawan diberi kesempatan untuk memberi masukan ke dalam proses perumusan tujuan dan standar atau setidaknya berkesempatan untuk mempertanyakan proses penetapan dan cara penerapan standar beserta tujuan tersebut. Kedua, penyampaian yang adil (a fair hearing) menjelaskan bahwa karyawan memiliki sarana untuk menunjukkan sudut pandang mereka sendiri tentang kinerja mereka. Karyawan diberi kesempatan untuk menjelaskan interpretasi mereka sendiri dan mengajukan argumen yang mendukung interpretasi tersebut. Ketiga, penilaian berdasarkan bukti (judgement based on the evidence) menerangkan bahwa data yang dibutuhkan untuk penilaian kinerja harus dikumpulkan dan keputusan harus didasarkan pada bukti. Tujuannya ialah agar penilai dapat melakukan penilaian secara konsisten, tanpa tekanan eksternal, korupsi, atau prasangka pribadi.

Mengacu pada model keadilan prosedural yang telah disebutkan, BUM Desa sebagai organisasi sektor publik juga dapat menerapkan model keadilan prosedural dengan komponen yang sama di antaranya: (1) pemberitahuan yang memadai (adequate notice) menerangkan bahwa hal-hal terkait unit usaha yang dijalankan BUM Desa harus dijelaskan kepada masyarakat desa oleh pengelola BUM Desa sehingga masyarakat paham dan dapat terlibat secara aktif dalam unit-unit usaha yang beroperasi. Komponen ini juga menjelaskan bahwa masyarakat desa memiliki kesempatan untuk bertanya terkait unit yang dijalankan oleh BUM Desa; (2) penyampaian yang adil (a fair hearing) menjelaskan bahwa masyarakat desa memiliki 
kesempatan untuk mengemukakan pendapatnya dalam pembuatan keputusan BUM Desa terkait kegiatan operasionalnya. Kesempatan dalam mengemukakan pendapat dapat disampaikan secara langsung melalui rapat maupun diskusi yang diadakan oleh BUM Desa. (3) penilaian berdasarkan bukti (judgement based on the evidence) menerangkan bahwa masyarakat desa memiliki kesempatan untuk memberikan kritik dan saran bagi BUM Desa sebagai bahan evaluasi bagi BUM Desa. Pemberian kritik dan saran dapat disampaikan secara langsung dalam rapat evaluasi yang diadakan oleh BUM Desa.

\section{METODE PENELITIAN}

\subsection{Sumber Data, Subjek, dan Fokus Penelitian}

Sumber data yang digunakan dalam penelitian ini merupakan data primer dan juga data sekunder. Data primer diperoleh dari kegiatan wawancara, observasi, dan dokumentasi. Sedangkan data sekunder diperoleh dari Anggaran Dasar dan Anggaran Rumah Tangga (AD/ART), notulensi serta Laporan Pertanggungjawaban (LPJ) BUM Desa. Penelitian berlokasi di BUM Desa Karya Lestari Manunggal Desa Kemasan, Kecamatan Sawit, Kabupaten Boyolali. Pelaksanaan penelitian dimulai pada bulan Agustus 2019 hingga bulan Januari 2020. Narasumber dipilih berdasarkan kajian yang menyatakan bahwa badan usaha milik desa merupakan sebuah unit usaha yang pengelolaannya dilakukan oleh pemerintah desa dan masyarakat desa (Ramadana et al., 2013). Oleh karena itu, narasumber yang dipilih untuk meneliti keadilan prosedural di BUM Desa ialah masyarakat desa serta pengurus BUM Desa di antaranya komisaris dan pengurus harian BUM Desa Kalem. Fokus pada penelitian ini ialah: (1) pemberitahuan yang memadai yaitu pemahaman yang diberikan terkait unit usaha yang dikelola BUM Desa sehingga masyarakat dapat berperan aktif dalam pelaksanaan dan pengelolaan unit usaha; (2) penyampaian yang adil yakni peluang dalam berpendapat yang dimiliki masyarakat desa dalam proses pembuatan arah kebijakan BUM Desa; (3) penilaian berdasarkan bukti yaitu kesempatan masyarakat desa dalam memberikan kritik dan saran terkait kinerja BUM Desa.

\subsection{Metode Penelitian dan Tahapan Analisis}

Penelitian ini merupakan penelitian yang dilakukan dengan metode deskriptif kualitatif. Penggunaan metode deskriptif kualitatif memberikan gambaran tentang suatu masalah, gejala, fakta, peristiwa dan realita secara luas dan mendalam sehingga diperoleh suatu pemahaman baru sehingga sesuai dengan tujuan penelitian yaitu untuk menjelaskan kondisi keadilan prosedural pada BUM Desa (Raco, 2010). Validitas dan reliabilitas dilakukan dengan mengkonfirmasi jawaban dari satu sumber data ke sumber data lainnya. Tahapan analisis data di antaranya: (1) mereduksi data yaitu meringkas data wawancara, observasi dan dokumentasi yang relevan dengan penelitian; (2) membandingkan kesesuaian data antara data wawancara, hasil pengamatan serta data sekunder yang diperoleh; (3) menyajikan data yaitu proses menampilkan data yang telah dibandingkan sehingga data tersebut terorganisir dan mudah untuk dipahami; (4) menganalisis data merupakan proses mencari makna dari data yang telah disajikan dengan cara menyesuaikan kejadian yang ada di lapangan dengan teori yang dikembangkan dari penelitian sebelumnya; dan (5) kesimpulan merupakan proses menentukkan hasil penelitian setelah dilakukan analisis data. 


\section{HASIL PENELITIAN DAN DISKUSI}

\subsection{Deskripsi Badan Usaha Milik Desa Karya Lestari Manunggal}

Desa Kemasan tempat berdirinya Badan Usaha Milik Desa Karya Lestari Manunggal (BUM Desa Kalem) merupakan desa yang terletak di Kecamatan Sawit, Kabupaten Boyolali, Jawa Tengah. Desa ini terdiri atas 20 RT dan 4 RW. Luas wilayah Desa Kemasan yaitu sebesar 125.7825 Ha dengan jumlah penduduk 3.213 jiwa dan 716 kepala keluarga. Sebagian besar mata pencaharian penduduk Desa Kemasan ialah sebagai petani serta sisanya bekerja sebagai pedagang dan pegawai negeri.

BUM Desa Kalem didirikan sejak bulan Juni tahun 2016 yang terletak di Komplek Balai Desa Kemasan, Balong RT.04/1. Pendirian BUM Desa Kalem diperkuat dengan payung hukum yaitu Peraturan Desa No. 13 Tahun 2016 tentang Pendirian Badan Usaha Milik Desa Karya Lestari Manunggal. Pembentukkan BUM Desa Kalem ditujukan untuk meningkatkan pendapatan masyarakat melalui penyerapan tenaga kerja desa dengan membuka lapangan pekerjaan dan peluang usaha ekonomi produktif. BUM Desa tersebut memiliki dua sumber penyertaan modal yaitu dari pemerintah dan masyarakat desa. Modal dari pemerintah yaitu berupa sejumlah uang yang diperoleh melalui APBDes (Anggaran Pendapatan dan Belanja Desa) sedangkan modal dari masyarakat diperoleh dari penjualan saham BUM Desa. Selain itu, BUM Desa Kalem menjalankan kegiatan operasionalnya dengan beberapa unit usaha di antaranya unit wisata (Dewa Emas), unit olahan ikan (Minamukti), unit air bersih (Pamsimas), dan unit pengolahan sampah (Sabamas). Namun pada tahun 2019, unit olahan ikan (Minamukti) tidak beroperasi secara penuh. Unit usaha tersebut hanya beroperasi jika ada kegiatan outbond dalam pembuatan nugget ikan.

Kelancaran dalam pelaksanaan kegiatan operasional yang dijalankan oleh BUM Desa Kalem diperkuat oleh pembentukan struktur organisasi yang jelas sehingga pembagian porsi dari setiap pemangku kepentingan menjadi jelas dan tidak tumpang tindih. Hal ini sesuai dengan Pasal 10 Peraturan Menteri Desa, Pembangunan Daerah Tertinggal, dan Transmigrasi Republik Indonesia Nomor 4 Tahun 2015 tentang Pendirian, Pengurusan dan Pengelolaan, dan Pembubaran Badan Usaha Milik Desa yang menyatakan susunan kepengurusan organisasi BUM Desa yang terdiri atas penasihat, pelaksana operasional, dan pengawas. Dalam peraturan tersebut juga menjelaskan bahwa BUM Desa merupakan induk dari unit-unit usaha yang dikembangkan masyarakat Desa (Menteri Desa, Pembangunan Daerah Tertinggal, dan Transmigrasi Republik Indonesia, 2015). Berikut adalah gambar susunan kepengurusan Badan Usaha Milik Desa Karya Lestari Manunggal: 


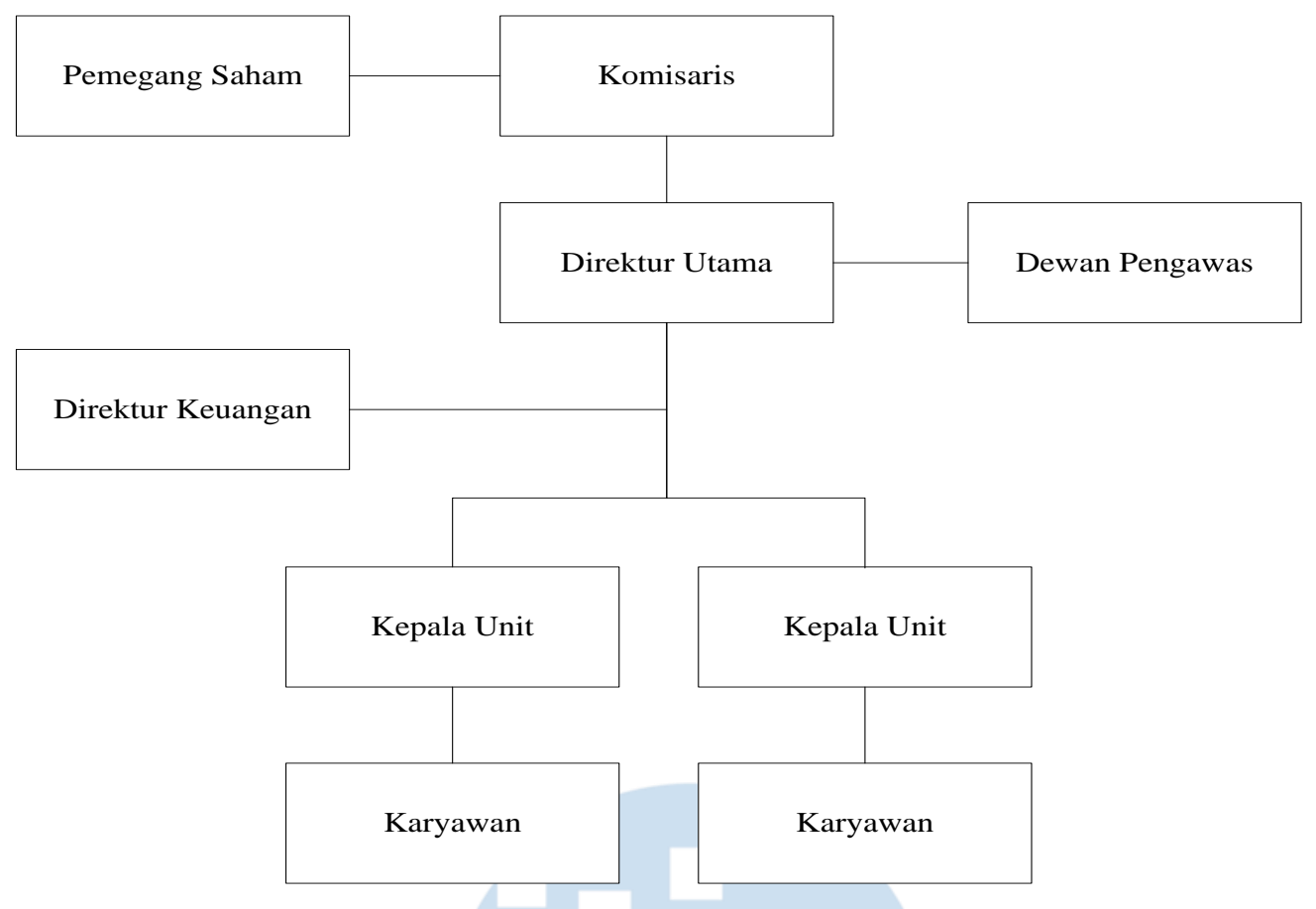

\section{Gambar 1 Susunan Kepengurusan BUM Desa Karya Lestari Manunggal}

Di sisi lain, kegiatan operasional BUM Desa Kalem juga didasari oleh visi yaitu menjadi wadah pengembangan potensi desa untuk menuju perekonomian desa yang mandiri dan berkesinambungan serta misi di antaranya: (1) mengoptimalkan potensi desa dengan kearifan lokal Desa Kemasan; (2) meningkatkan peran masyarakat desa dalam membangun perekonomian Desa Kemasan; (3) menjalin dan meningkatkan kemitraan di bidang usaha wisata dan bidang usaha lainnya, baik kemitraan jasa ataupun permodalan.

\subsection{Tata Kelola Badan Usaha Milik Desa Karya Lestari Manunggal}

Pengelolaan unit-unit usaha dibawah naungan BUM Desa Kalem menganut prinsip tata kelola perusahaan yang baik di antaranya transparansi, kemandirian, akuntabilitas, pertanggungjawaban, serta kesetaraan dan kewajaran. Transparansi dilakukan BUM Desa Kalem dengan cara melakukan koordinasi dengan komisaris dan pengawas sebelum melakukan pengambilan keputusan. Hal ini bertujuan agar adanya keterbukaan atas kegiatan yang dilaksanakan BUM Desa Kalem. Transparansi dilaksanakan melalui pembuatan website dan juga fanpage BUM Desa Kalem sehingga masyarakat dapat mengetahui kegiatan yang akan, sedang, ataupun dilakukan oleh BUM Desa Kalem. Kemudian, prinsip kemandirian dilakukan melalui tiga prinsip kerja BUM Desa Kalem yaitu mempertinggi kompetensi BUM Desa, memperbanyak kolaborasi melalui penawaran kerja sama, dan memperkecil kompetisi. Selanjutnya, akuntabilitas menggambarkan bahwa BUM Desa Kalem dalam melaksanakan kegiatan operasionalnya harus menjalin koordinasi dengan komisaris BUM Desa Kalem serta melaporkan arus kas atau kegiatan secara berkala sebagai wujud pertanggungjawaban pengurus. Di sisi lain, terdapat prinsip pertanggungjawaban yang menjelaskan bahwa pengelolaan BUM Desa Kalem harus disesuaikan dengan peraturan perundang-undangan yang berlaku. Terakhir, prinsip kesetaraan dan kewajaran menggambarkan bahwa dalam menjalankan kegiatan usahanya, BUM Desa Kalem memperlakukan para pemangku 
kepentingan secara setara dan wajar sesuai dengan peraturan yang berlaku. Perlakuan tersebut dikategorikan sebagai konsep keadilan dalam organisasi yaitu keadilan prosedural.

\subsection{Keadilan Prosedural di Badan Usaha Milik Desa Karya Lestari Manunggal Komponen 1: Pemberitahuan yang Memadai (Adequate Notice)}

Pada BUM Desa, pemberitahuan yang memadai menjelaskan tentang upaya BUM Desa dalam menyampaikan berbagai informasi secara lengkap mengenai prosedur pelaksanaan setiap unit usaha yang dikelola serta masalah-masalah yang dihadapi BUM Desa kepada masyarakat desa. Komponen ini tidak terlepas dari agenda tanya jawab antara pengurus harian BUM Desa dengan masyarakat desa. Hal ini bertujuan agar BUM Desa dapat melibatkan peran aktif masyarakat desa sehingga dapat meningkatkan kesejahteraan masyarakat desa sendiri. Oleh karena itu, pemahaman masyarakat desa tentang BUM Desa merupakan hal yang sangat penting. Sosialisasi dan studi banding ke desa lainnya merupakan cara yang ditempuh BUM Desa Kalem dalam rangka meningkatkan pemahaman masyarakat sehingga perkembangan unit usaha yang dikelola BUM Desa Kalem dapat mengalami peningkatan. Sosialisasi yang dilaksanakan oleh BUM Desa Kalem melibatkan perwakilan masyarakat di antaranya ketua RW Desa Kemasan dan PAGERMAS (Paguyuban Ketua RT se-Desa Kemasan) serta pengurus BUM Desa Kalem di antaranya pengawas, komisaris, serta pengurus harian BUM Desa. Sosialisasi tersebut biasanya dilaksanakan di balai desa Kemasan. Kemudian, agar informasi dari sosialisasi tersebut dapat tersampaikan ke seluruh masyarakat desa maka selanjutnya akan diadakan pertemuan berupa rapat oleh setiap RT. Hal ini sesuai dengan yang diungkapkan oleh Bapak R selaku Direktur Keuangan BUM Desa Kalem bahwa:

"Sosialisasi diadakan untuk menggerakkan unit usaha supaya maksimal. Untuk sosialisasi sendiri, kami mengundang perwakilan masyarakat dari RT dan RW. Untuk sampai ke masyarakat desa, kita lewatnya PAGERMAS. PAGERMAS kan RT-RT itu, jadi nanti penyampaiannya melalui rapat yang diadakan $R T$."

Pernyataan yang sama juga dinyatakan oleh Bapak S selaku komisaris BUM Desa Kalem, beliau menyatakan:

"Pengenalan unit usaha dilakukan melalui sosialisasi yang utamanya diberikan kepada perwakilan masyarakat desa. Kemudian dari sosialisasi tersebut akan dilanjutkan kepada masyarakat desa melalui pertemuan di setiap RT. Jadi setiap RT akan menyampaikan jadwal pertemuan kemudian kami akan datang ke sana untuk mengikuti pertemuan tersebut."

Hal yang serupa juga dinyatakan oleh Ibu P sebagai Direktur Utama BUM Desa Kalem:

"Untuk menjelaskan unit-unit usaha yang ada di BUM Desa, dilaksanakan juga sosialisasi ke RT-RT. Kami mengunjungi setiap RT mengikuti jadwal rapat yang dibuat oleh masing-masing RT."

Pernyataan tersebut diperkuat oleh Ibu Mm selaku ketua RT 03, RW 04 Desa Kemasan bahwa: "Setelah selesai mengikuti sosialisasi yang diadakan BUM Desa, kami langsung menentukan jadwal dan membuat undangan rapat dengan masyarakat desa untuk menyampaikan materi sosialisasi."

Sosialisasi yang dilaksanakan tidak hanya menjelaskan prosedur pelaksanaan yang dijalankan tiap unit usaha tetapi juga menjelaskan kebutuhan BUM Desa Kalem atas tenaga kerja untuk mengelola dan menjalankan unit usaha, hal ini sesuai dengan yang diutarakan Ibu P selaku Direktur Utama BUM Desa Kalem bahwa:

"Saat sosialisasi kami juga menyampaikan jika kami membutuhkan tenaga kerja dalam pengelolaan unit usaha. Kami berupaya dengan melakukan penawaran kerja sama 
dengan masyarakat dari UKM-UKM yang ada. Untuk sekarang UKM-UKM yang terlibat itu seperti penitipan makanan kemudian ada yang sering kita peseni kue untuk kegiatan rumah makan atau jika ada musdes. Kemudian ada juga UKM yang kita gunakan fasilitas dan tenaganya untuk paket outbond misalnya fasilitas pertanian untuk kegiatan bajak sawah serta tenaga kerja untuk edukasi pembuatan kerupuk kangkung dan pembuatan jamu. Selain itu, kami juga menyampaikan kebutuhan untuk tenaga kerja di unit usaha misalnya pelayan untuk rumah makan. Intinya seluruh informasi terkait kebutuhan tenaga kerja kami sampaikan di sosialisasi-sosialisasi."

Pernyataan tersebut diperkuat oleh Ibu Mm selaku ketua RT 03, RW 04 terDesa Kemasan, beliau mengatakan:

"Dalam sosialisasi yang disampaikan yaitu proses jalannya unit usaha hingga penawaran kerja sama untuk UKM-UKM yang ada di desa."

Sosialisasi juga tidak terlepas dari agenda tanya-jawab antara masyarakat desa dengan pengurus harian BUM Desa Kalem. Hal ini sesuai dengan yang diungkapkan oleh Ibu P sebagai Direktur Utama BUM Desa Kalem:

"Masyarakat tentu diberi kesempatan untuk bertanya agar masyarakat jelas dengan materi sosialisasi."

Pernyataan tersebut diperkuat oleh Bapak S selaku komisaris BUM Desa Kalem yang menyatakan:

"Jelas masyarakat diberikan kesempatan untuk bertanya dalam sosialisasi yang diadakan agar masyarakat paham betul dengan materi yang disajikan."

Di sisi lain, studi banding juga dilaksanakan oleh BUM Desa Kalem untuk dapat meningkatkan pemahaman pengurus unit usaha beserta pengurus harian BUM Desa dalam mengelola unit-unit usaha yang dijalankan BUM Desa Kalem. Desa yang dituju BUM Desa Kalem dalam rangka pelaksanaan studi banding merupakan desa yang memiliki BUM Desa yang pengelolaan unit usahanya lebih berkembang. Mengacu pada sosialisasi SABAMAS yang dilaksanakan pada 28 Agustus 2019, BUM Desa Kalem merencanakan studi banding ke BUM Desa Amarta, Pandowoharjo, Sleman, Yogyakarta yang telah direalisasikan pada 16 September 2019. Tujuan studi banding tersebut ialah untuk mempelajari siklus pengelolaan sampah di BUM Desa tersebut. Studi banding dilakukan agar dapat mendukung peningkatan kualitas pelayanan dan pengelolaan unit usaha yang dikelola BUM Desa Kalem.

Meskipun sosialisasi dan studi banding sudah dilaksanakan, tetapi BUM Desa Kalem masih memiliki kelemahan dari segi ketersediaan sumber daya manusia (SDM). Rendahnya minat masyarakat untuk terlibat dalam mengembangkan BUM Desa Kalem merupakan salah satu faktor penghambat perkembangan BUM Desa Kalem. Keterlibatan masyarakat yang dimaksud ialah partisipasi masyarakat desa untuk ikut serta dalam berbagai peluang kerja yang disediakan BUM Desa Kalem. Hal ini sesuai dengan yang dinyatakan oleh Ibu P sebagai Direktur Utama BUM Desa Kalem:

"Masyarakat desa tidak terlalu berminat untuk terlibat di BUM Desa. Jadi dalam pelaksanaan operasi unit-unit usaha, kami juga menggunakan tenaga dari luar desa Kemasan. Seharusnya BUM Desa Kalem ini dijalankan oleh masyarakat desa sendiri, tetapi jika kita terus mengharapkan keterlibatan langsung oleh masyarakat desa maka BUM Desa akan susah untuk berkembang."

Pernyataan ini diperkuat oleh Ibu Mr selaku masyarakat yang menjalankan UKM Kerupuk Sayur, beliau mengatakan: 
"Sebenarnya kekurangan SDM di BUM Desa itu karena minat masyarakat untuk bekerja kurang. Jadi tidak semua masyarakat desa terlibat aktif dalam pelaksanaan operasional BUM Desa maupun unit-unit usahanya."

Pemberitahuan yang secara memadai mengenai BUM Desa hingga ke unit-unit usahanya memberikan memberikan manfaat penting bagi tingkat keterlibatan masyarakat desa. Di BUM Desa Kalem, penyampaian informasi yang memadai diupayakan melalui sosialisasi dan pelaksanaan studi banding ke BUM Desa lain yang lebih berkembang. Pelaksanaan sosialisasi oleh BUM Desa Kalem dilakukan sebelum dan saat unit-unit usaha sudah dijalankan. Dalam sosialisasi, juga terdapat sesi tanya-jawab yang bertujuan agar masyarakat paham mengenai materi sosialisasi yang sudah disampaikan. Hal ini sesuai dengan model keadilan prosedural yang dikemukakan oleh Folger et al. (1992) bahwa pemberitahuan yang memadai merupakan model keadilan yang ditempuh dengan menerbitkan, mendistribusikan, serta menjelaskan tujuan dan standar secara memadai sebelum ditetapkan.

Selain itu, penyampaian informasi yang memadai oleh BUM Desa Kalem melalui sosialisasi bermanfaat agar perekonomian desa Kemasan dapat terus berkembang. Perkembangan perekonomian desa diupayakan BUM Desa Kalem dengan menawarkan kerja sama dengan UKM-UKM yang ada di desa Kemasan. BUM Desa Kalem juga menyediakan lapangan pekerjaan untuk mengelola unit-unit usaha yang ada di BUM Desa Kalem. Penawaran kerja sama dan penyediaan lapangan kerja diinformasikan secara detail kepada masyarakat desa melalui sosialisasi yang diadakan BUM Desa Kalem. Kondisi ini sesuai dengan pendapat oleh Budiono, (2015); Hayyuna et al. (2014); Kasila dan Kolopaking, (2018); Suryana et al. (2015) yang menyatakan bahwa BUM Desa berperan untuk menciptakan kemandirian perekonomian desa, mengentas kemiskinan yang terjadi di wilayah pedesaan, dan meningkatkan kesejahteraan masyarakat melalui pemanfaatan produk lokal yang diproduksi oleh masyarakat desa. Meskipun demikian, peran BUM Desa tidak dapat dilaksanakan dengan baik jika masyarakat desa tidak terlibat aktif. Kondisi inilah yang tercermin di BUM Desa Kalem. Hal tersebut dikarenakan kurangnya minat masyarakat desa Kemasan untuk bekerja sama dengan BUM Desa Kalem. Jadi meskipun BUM Desa Kalem berupaya keras dalam memperkenalkan unitunit usahanya hingga menawarkan kerja sama, tetapi jika tidak ada timbal balik dari masyarakat maka BUM Desa Kalem tidak dapat mengalami perkembangan. Oleh sebab itu, BUM Desa Kalem belum mampu menerapkan model keadilan prosedural berdasarkan komponen pemberitahuan yang memadai karena komponen ini membutuhkan hubungan timbal balik antara BUM Desa dengan masyarakat desa.

\section{Komponen 2: Penyampaian yang Adil (A Fair Hearing)}

Penyampaian yang adil menjelaskan tentang kesempatan yang diperoleh masyarakat desa untuk mengemukakan pendapatnya terkait potensi desa dalam pembuatan arah kebijakan BUM Desa. Arah kebijakan yang dimaksud merupakan rumusan perencanaan yang dibuat untuk menjalankan unit-unit usaha yang dikelola BUM Desa. Pembuatan arah kebijakan di BUM Desa Kalem dilakukan dalam rapat pengurus yang terdiri atas pengawas, komisaris, dan pengurus harian BUM Desa Kalem. Pelaksanaan rapat pengurus biasanya dilakukan di kantor BUM Desa Kalem. Dalam proses pembuatan kebijakan BUM Desa, masyarakat desa Kemasan tidak dilibatkan secara langsung. Hal ini sesuai dengan pernyataan oleh Bapak $\mathrm{R}$ selaku Direktur Keuangan BUM Desa Kalem:

"Pembuatan arah kebijakan biasanya dilakukan oleh pengurus BUM Desa saja yang arahan utamanya dari komisaris BUM Desa yaitu Bapak Kepala Desa."

Pernyataan tersebut sesuai dengan tugas dan kewenangan dari pengurus harian, pengurus unit usaha, komisaris, dan pengawas BUM Desa Kalem yang tercantum dalam 
Anggaran Rumah Tangga Badan Usaha Milik Desa Karya Lestari Manunggal Pasal 10, Pasal 17, Pasal 27, Pasal 33, dan Pasal 36. Tugas yang dimaksud merupakan tugas pengurus BUM Desa Kalem dalam merumuskan kebijaksanaan umum BUM Desa Kalem (Badan Usaha Milik Desa Karya Lestari Manunggal, 2016b).

Walaupun demikian, masyarakat desa tetap terlibat dalam proses pembuatan arah kebijakan BUM Desa Kalem tetapi secara tidak langsung. Hal ini dikarenakan sebelum diadakan rapat pengurus BUM Desa, telah dilaksanakan Musyawarah Rencana Pembangunan Desa (Musrenbangdes). Dalam musyawarah tersebut, perwakilan masyarakat desa yaitu ketua RW, PAGERMAS, pemegang saham BUM Desa, serta perwakilan setiap UKM diberi kesempatan untuk menyampaikan ide-ide ataupun saran dalam rangka mendukung kemajuan desa. BUM Desa Kalem dalam hal ini berperan sebagai sarana dalam mendukung kemajuan desa sehingga ide ataupun saran yang disampaikan sejalan dengan pembuatan arah kebijakan BUM Desa. Hal ini sesuai dengan pernyataan oleh Bapak R selaku Direktur Keuangan BUM Desa Kalem:

"Masyarakat dilibatkan mba dalam pembuatan arah kebijakan BUM Desa Kalem tetapi tidak dalam forum BUM Desa melainkan dalam forum musrenbangdes. Dalam musrenbangdes masyarakat diminta gagasan apapun untuk kemajuan desa, misalnya pengembangan sarana prasarana, pengembangan ukm, pengembangan potensi desa, dan lain-lain. Dari gagasan-gagasan tersebut, kami kemudian merancang arah kebijakan BUM Desa yang dapat ditempuh."

Keterlibatan masyarakat desa untuk menyampaikan pendapatnya dalam proses pembuatan arah kebijakan BUM Desa merupakan kunci dari komponen penyampaian yang adil. Meskipun masyarakat tidak dilibatkan secara langsung dalam rapat pengurus BUM Desa Kalem, tetapi masyarakat tetap dilibatkan dalam penetapan arah kebijakan BUM Desa Kalem melalui masukan berupa saran-saran yang disampaikan dalam Musyawarah Rencana Pembangunan Desa (Musrenbangdes). Hal ini sesuai dengan pendapat dari Folger et al. (1992) yang mengungkapkan bahwa dalam model keadilan prosedural untuk komponen penyampaian yang adil, karyawan diberi kesempatan untuk menjelaskan sudut pandang mereka sendiri dan mengajukan argumen yang mendukung interpretasi tersebut. Oleh karena itu, BUM Desa Kalem mampu menerapkan model keadilan prosedural berdasarkan penyampaian yang adil. Hal ini dikarenakan dalam pengelolaan BUM Desa Kalem khususnya dalam menetapkan arah kebijakan BUM Desa, masyarakat dilibatkan secara aktif sehingga arah kebijakan yang ditetapkan menjadi sesuai dengan potensi dan keterampilan masyarakat.

\section{Komponen 3: Penilaian Berdasarkan Bukti (Judgement Based on The Evidence)}

Penilaian berdasarkan bukti menerangkan tentang peluang masyarakat desa dalam menyampaikan kritik dan saran mengenai kinerja BUM Desa selama periode berjalan. Komponen ini bertujuan agar BUM Desa mampu meningkatkan kualitas kinerjanya pada periode selanjutnya. Di BUM Desa Kalem, komponen ini dilaksanakan melalui musyawarah desa pada awal tahun. Musyawarah desa tersebut dilaksanakan di balai Desa Kemasan. Pihakpihak yang diundang hadir di antaranya pengurus BUM Desa, ketua RW, PAGERMAS, pemegang saham, dan perwakilan setiap UKM. Dalam musyawarah desa, laporan pertanggungjawaban disajikan dan disampaikan oleh pengurus harian BUM Desa Kalem yang didampingi oleh komisaris dan pengawas BUM Desa Kalem. Laporan pertanggungjawaban tersebut berisikan arah kebijakan yang sudah ditempuh, laba usaha, dan bagi hasil pemegang saham periode sebelumnya diikuti dengan penyampaian program kerja periode baru dan rencana-rencana pengembangan BUM Desa. Hal ini sesuai dengan keterangan dari Bapak R selaku Direktur Keuangan BUM Desa Kalem: 
"Penyusunan laporan keuangan BUM Desa dilakukan oleh direktur keuangan BUM Desa dengan menggabungkan laporan-laporan keuangan dari tiap unit usaha. Sedangkan pembuatan laporan pencapaian arah kebijakkan itu tanggung jawab dari saya dan Ibu P selaku Direktur Utama BUM Desa. Laporan pertanggungjawaban tersebut akan dibuat saat akhir periode yaitu pada saat akhir tahun. Pada awal tahun akan diadakan musyawarah desa yang ditujukan untuk memaparkan laporan keuangan, hasil pencapaian BUM Desa, dan perencanaan ke depannya."

Peraturan yang tertera dalam Anggaran dasar Badan Usaha Milik Desa (BUM Desa Karya Lestari Manunggal) Pasal 17c menyebutkan bahwa musyawarah desa merupakan lembaga tertinggi dalam pengambilan keputusan yang memiliki kewenangan dalam memilih dan/atau menolak laporan pertanggungjawaban pengurus (Badan Usaha Milik Desa Karya Lestari Manunggal, 2016a). Peraturan ini memberikan gambaran bahwa adanya kesempatan yang diberikan bagi perwakilan masyarakat yang hadir untuk memberikan kritik dan saran terkait laporan pertanggungjawaban BUM Desa Kalem untuk didiskusikan secara bersama. Hal ini sesuai dengan pernyataan oleh Ibu P selaku Direktur Utama BUM Desa Kalem, beliau menyatakan:

"Iya, setelah penyampaian laporan BUM Desa Kalem selesai, perwakilan masyarakat yang hadir diberi kesempatan untuk memberikan kritik dan saran."

Bapak S sebagai pemegang saham BUM Desa Kalem juga mengaku bahwa:

"Setelah pemaparan laporan pertanggungjawaban BUM Desa Kalem dilaksanakan, diberikan kesempatan bagi tokoh masyarakat yang hadir untuk memberikan masukan."

Pernyataan-pernyataan diatas diperkuat oleh hasil observasi musyawarah desa yang dilaksanakan pada 25 Januari 2020. Musyawarah desa yang dimulai pada pukul 10.00 WIB tersebut dihadiri oleh ketua RW, PAGERMAS, para pemegang saham, dan perwakilan setiap UKM. Dalam musyawarah desa tersebut dipaparkan laporan mengenai BUM Desa Kalem dari arah kebijakan yang ditempuh hingga perencanaan BUM Desa pada tahun 2020 oleh Bapak R selaku Direktur Keuangan BUM Desa Kalem. Setelah pemaparan laporan BUM Desa selesai, diberikan kesempatan bagi perwakilan masyarakat yang hadir untuk memberikan kritik, saran, maupun pertanyaan kepada pengurus harian BUM Desa Kalem. Pada kesempatan tersebut, salah satu perwakilan masyarakat yang berpartisipasi dalam agenda tersebut ialah Bapak $\mathrm{S}$ selaku pemegang saham BUM Desa Kalem, beliau memberikan kritik dan saran terkait keterlibatan BUM Desa dalam berbagai kegiatan Desa Kemasan. Kritik dan saran tersebut kemudian direspon dengan baik oleh pengurus harian BUM Desa Kalem.

Penilaian berdasarkan bukti berarti bahwa masyarakat desa memiliki peluang untuk menyampaikan pendapatnya berdasarkan pengalaman terhadap kinerja BUM Desa. Pendapat yang disampaikan dapat berupa kritik dan saran. Tujuan dari pemberian kritik dan saran ialah sebagai acuan dalam meningkatkan kualitas BUM Desa karena melalui hal tersebut, BUM Desa dapat menemukan kelebihan maupun kekurangan yang harus dikembangkan maupun diperbaiki. Di BUM Desa Kalem, sudah diterapkan agenda untuk menerima kritik dan saran dalam setiap pelaksanaan musyawarah desa. Hal ini menggambarkan perlakuan yang adil karena masyarakat desa diberikan hak untuk memberikan masukkan-masukkan untuk kemajuan BUM Desa. Kondisi ini sesuai dengan pendapat dari Agoes dan Ardana, (2014); Cropanzano et al. (2011) yang menyatakan bahwa perlakuan yang setara berarti para pengelola usaha dapat memperlakukan semua pemangku kepentingan secara adil dan setara yang bebas dari bias dan representatif dari pemangku kepentingan yang relevan.

Kritik dan saran yang diberikan merupakan bagian dari penilaian masyarakat terhadap kinerja BUM Desa Kalem selama periode berjalan. Selain kritik dan saran, pertanyaan juga 
dapat diajukan masyarakat desa kepada pengurus harian mengenai laporan keuangan yang telah dipaparkan. Melalui kritik, saran, dan pertanyaan inilah, musyawarah desa dapat memutuskan penerimaan atau penolakan terhadap laporan pertanggungjawaban pengurus BUM Desa Kalem. Hal ini sudah sesuai dengan model keadilan yang diutarakan oleh Folger et al. (1992) bahwa penilaian berdasarkan bukti (judgement based on the evidence) menerangkan bahwa data yang dibutuhkan untuk penilaian kinerja harus dikumpulkan dan keputusan harus didasarkan pada bukti.

Selain itu, kesempatan yang diberikan kepada masyarakat untuk mengungkapkan kritik dan saran memberikan gambaran bahwa pengelolaan BUM Desa Kalem tidak hanya dilakukan oleh pemerintah desa dan pengurus harian BUM Desa tetapi juga melibatkan masyarakat desa Kemasan. Kondisi ini sesuai dengan pendapat yang dikemukakan oleh Iskamto et al. (2018); Ramadana et al. (2013) yang menyatakan bahwa pengelolaan BUM Desa dilakukan oleh pemerintah desa dan masyarakat desa serta harus dapat mempertahankan kualitas dari produk maupun jasa yang disediakan. Oleh karena itu, BUM Desa Kalem sudah mampu dalam menerapkan keadilan prosedural berdasarkan komponen penilaian berdasarkan bukti. Hal ini dikarenakan adanya keterlibatan masyarakat melalui penyampaian kritik, saran, maupun pertanyaan kepada pengurus harian BUM Desa Kalem mengenai pertanggungjawaban kinerja BUM Desa selama periode berjalan sehingga kualitas BUM Desa Kalem dapat dipertahankan bahkan ditingkatkan.

\section{SIMPULAN, KETERBATASAN DAN SARAN \\ 5.1. Kesimpulan}

Hasil penelitian yang diperoleh, masih terdapat komponen keadilan prosedural yang belum mampu dilaksanakan Badan Usaha Milik Desa Karya Lestari Manunggal, Desa Kemasan, Kecamatan Sawit, Kabupaten Boyolali, Jawa Tengah. Komponen pertama yaitu pemberitahuan yang memadai merupakan komponen yang belum dapat terealisasi karena keterbatasan sumber daya manusia yang memadai sehingga sosialisasi dan studi banding yang dilaksanakan menjadi kurang berdampak pada masyarakat desa Kemasan. Kemudian dua komponen terakhir yaitu penyampaian yang adil lalu penilaian berdasarkan bukti merupakan komponen yang sudah mampu direalisasikan BUM Desa Kalem. Hal ini dikarenakan adanya ketersediaan kesempatan bagi masyarakat desa melalui Musyawarah Rencana Pembangunan Desa maupun Musyawarah Desa sehingga dalam upaya peningkatan kualitas BUM Desa Kalem, pengurus BUM Desa tidak bekerja sendiri melainkan juga melibatkan masyarakat Desa Kemasan.

\subsection{Keterbatasan Penelitian}

Keterbatasan dari penelitian ini ialah peneliti tidak dapat mengikuti dan mendapatkan notulensi Musyawarah Perencanaan dan Pembangunan Desa karena adanya kendala pada waktu dan akses yang diberikan. Hal ini menyebabkan pembahasan komponen penyampaian yang adil hanya didasarkan pada kegiatan wawancara

\subsection{Saran untuk Penelitian Selanjutnya}

Penelitian selanjutnya dapat dilakukan untuk menyelidiki keadilan organisasi lainnya yaitu keadilan distributif dan keadilan interaktif pada BUM Desa. Selain itu, saran bagi Badan Usaha Milik Desa Karya Lestari Manunggal ialah sebaiknya pelatihan untuk masyarakat Desa Kemasan perlu untuk dilakukan. Sosialisasi dan studi banding juga seharusnya tidak sebatas penjelasan terhadap hal-hal yang berkaitan dengan unit usaha yang dikelola BUM Desa melainkan juga ada penyampaian secara berulang mengenai manfaat BUM Desa serta dampaknya secara riil bagi masyarakat jika masyarakat terlibat aktif dan kualitas BUM Desa meningkat. Bagi Dinas Pemberdayaan Masyarakat dan Desa agar dapat 
mengawasi proses pelaksanaan dan pembuatan arah kebijakan BUM Desa Kalem khususnya pada kegiatan sosialisasi.

\section{REFERENSI}

Agoes, S., dan Ardana, I. C. (2014). Etika Bisnis dan Profesi: Tantangan Membangun Manusia Seutuhnya (Revisi). Jakarta: Salemba Empat.

Arifuddin, M., Safaruddin, dan Falziah. (2017). Persepsi Pengelola Keuangan Desa dalam Mewujudkan Transparansi dan Akuntabilitas Keuangan Desa Di Kecamatan Mawasangka Kabupaten Buton Tengah. Jurnal Akuntansi Dan Keuangan, 2, 23-38.

Artati, A. K., dan Utami, I. (2020). Can and will village-owned enterprises provide the financial statement accountability? International Journal of Scientific and Technology Research, 9(4), 647650.

Badan Usaha Milik Desa Karya Lestari Manunggal. Anggaran Dasar Badan Usaha Milik Desa (BUM Desa Karya Lestari Manunggal) (2016). Indonesia.

Badan Usaha Milik Desa Karya Lestari Manunggal. Anggaran Rumah Tangga Badan Usaha Milik Desa "Karya Lestari Manunggal (Kalem)" (2016). Indonesia.

Berdesa. (2017). Membangun Peran BUM Desa Sebagai Pengentas Ketidakberdayaan Ekonomi Warga. Retrieved June 6, 2019, from http://www.berdesa.com/membangun-peran-bumdesa-pengentasketidakberdayaan-ekonomi-warga/

Bohle, S. A. L., dan Alonso, A. R. M. (2016). The Effect of Procedural Fairness and Supervisor Support in The Relationship Between Job Insecurity and Organizational Citizenship Behavior. Review Of Business Management, 19(65), 337-357. https://doi.org/10.7819/rbgn.v0i0.3023

Budiono, P. (2015). Implementasi Kebijakan Badan Usaha Milik Desa (Bumdes) Di Bojonegoro (Studi di Desa Ngringinrejo Kecamatan Kalitidu Dan Desa Kedungprimpen Kecamatan Kanor). Jurnal Politik Muda, 4(1), 116-125.

Canada, K. E., dan Watson, A. C. (2013). "Cause Everybody Likes to Be Treated Good”: Perceptions of Procedural Justice Among Mental Health Court Participants. American Behavioral Scientist, 57(2), 209-230. https://doi.org/10.1177/0002764212465415

Clarke, C., Harcourt, M., dan Flynn, M. (2013). Clinical Governance, Performance Appraisal and Interactional and Procedural Fairness at a New Zealand Public Hospital. Journal of Business Ethics, 117(3), 667-678. https://doi.org/10.1007/s10551-012-1550-9

Cropanzano, R., Bowen, D. E., dan Gilliland, S. W. (2011). The Management of Organizational Justice. Academy of Management Perspectives, 21(4), 34-48. https://doi.org/10.5465/amp.2007.27895338

Farokhah, L., dan Sapoetra, Y. A. (2018). Perancangan Aplikasi "Village Entrepreneurship" untuk Meningkatkan Pengelolaan Badan Usaha Milik Desa (BUMDes). Seminar Nasional Sistem Informasi, 1073-1082.

Folger, R., Konovsky, M., dan Cropanzano, R. (1992). A Due Process for Performance Appraisal. Research in Organizational Behaviour, 14, 129-177.

Goodman-Delahunty, J., O’Brien, K., dan Gumbert-Jourjon, T. (2014). Police Professionalism in Interviews with High Value Detainees: Cross-Cultural Endorsement of Procedural Justice. The Journal of the Institute of Justice and International Studies, 1-18.

Hayyuna, R., Pratiwi, R. N., dan Mindarti, L. I. (2014). Strategi Manajemen Aset BUMDES Dalam Rangka Meningkatkan Pendapatan Desa (Studi pada BUMDES di Desa Sekapuk Kecamatan Ujungpangkah, Kabupaten Gresik). Jurnal Administrasi Publik, 2(1), 1-5.

Irawan, L., dan Sudarma, K. (2016). Pengaruh Keadilan Distributif dan Keadilan Prosedural pada Komitmen Afektif melalui Kepuasan Kerja. Management Analysis Journal, 5(2), 149-155.

Iskamto, D., Risman, dan Alwifari, A. (2018). Pengaruh Kualitas Pelayanan Terhadap Kepuasan Nasabah di Badan Usaha Milik Desa (BUMDes). Eko Dan Bisnis (Riau Economics and Business Reviewe), 9(3), 186-194.

Josef, E. S. (2017). Pengaruh Dimensi Keadilan Organisasional terhadap Perilaku Kerja Kontraproduktif Karyawan (Studi pada Divisi Atk-Mart PT. Gading Murni Surabaya). Jurnal Ilmu Manajemen, 
$5(1), 1-9$.

Kasila, M., dan Kolopaking, L. M. (2018). Partisipasi Pemuda Desa dalam Perkembangan Usaha BUMDes "Tirta Mandiri” (Studi di Desa Ponggok, Kecamatan Polanharjo, Kabupaten Klaten, Provinsi Jawa Tengah). Jurnal Sains Komunikasi Dan Pengembangan Masyarakat [JSKPM], 2(1), 43-58. https://doi.org/10.29244/jskpm.2.1.43-58

Kementerian Desa, P. D. T., dan Indonesia, D. T. R. I. (2019). Pusat Data Desa Indonesia. Retrieved June 6, 2019, from https://pddi.kemendesa.go.id/

Maspaitella, B. J., Tri. A, Y., Siswanto, Santoso, H., dan Bakhtiar, A. (2018). Pengaruh Keadilan Organisasional Terhadap Kepuasan Kerja dan Dampaknya terhadap Komitmen dan Intensi Keluar Di PT Indonesia Power UBP Semarang. Seminar Nasional IENACO, 498-507.

Menteri Desa, Pembangunan Daerah Tertinggal, dan Transmigrasi Republik Indonesia. Peraturan Menteri Desa, Pembangunan Daerah Tertinggal, dan Transmigrasi Republik Indonesia, Pub. L. No. 4, 7 (2015). Indonesia.

Menteri Keuangan Republik Indonesia. (2017). Dana Desa untuk Kesejahteraan Masyarakat: Menciptakan Lapangan Kerja, Mengatasi Kesenjangan, dan Mengentaskan Kemiskinan. Jakarta.

Nahruddin, Z. (2014). Akuntabilitas dan Transparansi Pengelolaan Dana Alokasi Desa di Desa Pao-Pao Kecamatan Tanete Rilau Kabupaten Barru. Jurnal Ilmu Pemerintahan, 4(2), 193-201.

Negrut, V., Costache, M. P., Maftei, J., Coman, V. L., Matei, D., dan Negrut, A. (2010). The Aspects of Good Governance in the Context of Globalization. In Proceedings of the 21st International DAAAM Symposium (Vol. 21, pp. 1259-1261).

Nugrahaningsih, P., Falikhatun, F., dan Winarna, J. (2016). Optimalisasi Dana Desa Dengan Pengembangan Badan Usaha Milik Desa (BUM Des) Menuju Desa Mandiri. Jurnal Akuntansi Dan Bisnis, 16(1), 37-45. https://doi.org/10.20961/jab.v16i1.190

Pahlawan, D., Purnomo, H., dan Murniati, W. (2018). Analisis Pengaruh Penerapan Good Corporate Governance terhadap Kinerja Perusahaan (Studi pada Perusahaan Manufaktur yang terdaftar di BEI Periode 2014-2016). Jurnal Riset Akuntansi, 1(1), 68-77.

Prasojo, E., Ridwan, I., Kurniawan, T., dan Karyana, A. (2014). Materi Pokok Pemerintahan Daerah (Kedua). Tangerang Selatan: Universitas Terbuka.

Ramadana, C. B., Ribawanto, H., dan Suwondo. (2013). Keberadaan Badan Usaha Milik Desa (BUMDes) sebagai Penguat Ekonomi Desa (Studi di Desa Landungsari, Kecamatan Dau, Kabupaten Malang). Jurnal Administrasi Publik (JAP), 53(9), 1689-1699. https://doi.org/10.1017/CBO9781107415324.004

Septiawan, B. (2018). Pengaruh Pelaksanaan Audit Internal dan Komitmen Organisasi Terhadap Good Corporate Governance (Survey Pada 3 BUMN yang Berkantor Pusat di Kota Bandung). Seminar Nasional I Universitas Pamulang, 1-9.

Shaffitri, L. R., Syaukat, Y., dan Ekayani, M. (2015). Peranan BUMDes dalam Pengelolaan Limbah Cair Tahu dan Pemanfaatan Biogas. Risalah Kebijakan Pertanian Dan Lingkungan, 2(2), 136 143. https://doi.org/10.20957/jkebijakan.v2i2.10984

Simcock, N. (2016). Procedural Justice and The Implementation of Community Wind Energy Projects: A Case Study from South Yorkshire, UK. Land Use Policy, 59, 467-477. https://doi.org/10.1016/j.landusepol.2016.08.034

Sugiarti, E., dan Yudianto, I. (2017). Analisis Faktor Kompetensi Sumber Daya Manusia, Pemanfaatan Teknologi Informasi, dan Partisipasi Penganggaran Terhadap Akuntabilitas Pengelolaan Dana Desa (Survei Pada Desa-Desa di Wilayah Kecamatan Klari, Kecamatan Karawang Timur, Kecamatan Majalaya dan. In Proceedings Profesionalisme Akuntan Menuju Sustainable Business Practice (pp. 580-590).

Suryana, I. M., Setiyono, T. J., dan Murdoyuwono, C. S. (2015). Pemberdayaan Kelompok Tani Melalui BUMDes (Badan Usaha Milik Desa). Jurnal Bakti Saraswati, 4(2), 138-144.

Syah, D. H. (2013). Pengaruh Keadilan Prosedural Terhadap Kinerja Manajerial Pada Inna Dharma Deli. Jurnal Pengabdian Masyarakat, 19.

Tantri, M. D., dan Utami, I. (2019). Pengelolaan Dana BUMDes Bersama "Utama": Kajian Aspek Transparansi dan Responsibilitas, XIII(1), 1-17.

Wulandari, N., dan Utami, I. (2020). Eksplorasi Mekanisme Pertanggungjawaban Badan Usaha Milik 
Desa. Jurnal Ekonomi, Manajemen, Akuntansi Dan Perpajakan, 3(1). https://doi.org/https://doi.org/10.24167/jemap.v3i1.2483

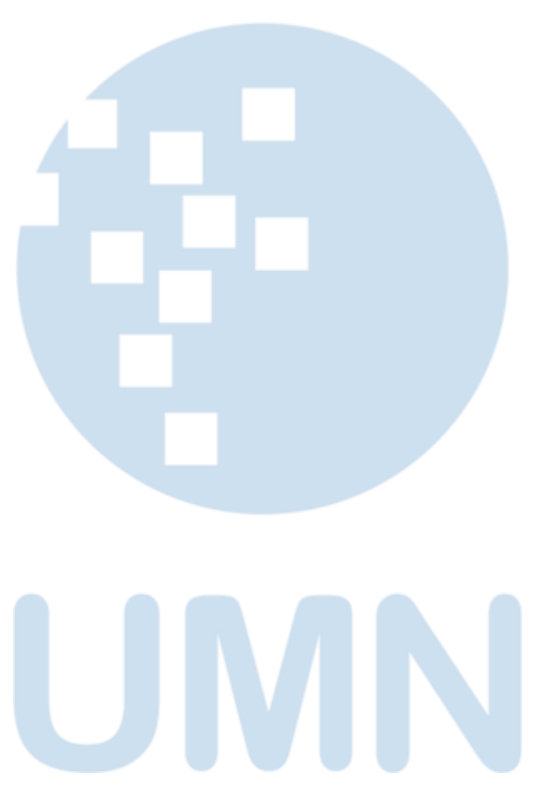

